\title{
Folic acid does not improve semen parametrs in subfertile men: A double-blin, randomized, placebo-controlled study
}

\section{Folic acid does not improve semen parametrs}

\author{
Tatiana Moreira da Silva ${ }^{1 *}$, Mônica Canêdo Silva Maia ${ }^{1}$, Jalsi Tacon Arruda ${ }^{1,2}$, Fabiana Carmo Approbato ${ }^{1}$, Carolina \\ Rodrigues Mendonça ${ }^{1,2}$, Mário Silva Approbato ${ }^{3}$
}

${ }^{1}$ Post Graduate Program in Health Sciences, School of Medicine, Federal University of Goias

2 J.T. Arruda and C.R. Mendonça are recipients of a Fellowship from Coordenação de Aperfeiçoamento de Pessoal de Nível Superior (CAPES)

${ }^{3}$ Director of Human Reproduction Laboratory in the Clinics Hospital, Department of Obstetrics and Gynaecology, Federal University of Goias (UFG), Goiânia, Goiás, Brazil

This research was selected for oral presentation at the XVI Brazilian Congress of Assisted Reproduction, in 2012.

\begin{abstract}
Objective: It is thought that oral supplementation with antioxidants might reduce damage caused by reactive oxygen species in the seminal fluid, and as a consequence it increases the fertilizing capacity of spermatozoa due to improvement of sperm parameters.

Methods: The aim of this research is to evaluate the effect of folic acid supplementation, by semen analysis, in 49 subfertile men with the median age being 35.3 years ( \pm 7.7$)$. The experimental group $(n=23)$ received $5 \mathrm{mg}$ of folic acid daily and the control group $(n=26)$ received placebo, both groups were treated for three months. In order to confirm the condition of sub-fertility, two spermogram were performed with an interval of 15 days between the first and the second test. Moreover, sexual intercourse and masturbation abstinence were required for two to five days before collecting the semen samples (according to the WHO recommendations). Pre and post-intervention examination was performed in the same laboratory by two professionals, according to the WHO criteria, 1999. The chi-square test was applied for both groups.

Results: There was no statistically significant improvement in any of the following parameters: concentration, motility, morphology and vitality of the spermatozoa.

Conclusion: Folic acid treatment alone in doses of $5 \mathrm{mg} / \mathrm{day}$ does not improve sperm parameters in sub-infertile men. Keywords: male infertility; antioxidant supplements; folic acid, spermogram; oxidative stress.
\end{abstract}

\section{RESUMO}

Objetivo: Acredita-se que a suplementação oral com antioxidantes possa reduzir os danos causados por espécies reativas de oxigênio no líquido seminal aumentando a capacidade de fertilização dos espermatozóides devido à melhora dos parâmetros espermáticos.

Métodos: O objetivo desse estudo foi avaliar o efeito da suplementação com ácido fólico no espermograma de 49 homens subférteis com faixa etária média de 35,3 anos $( \pm 7,7)$. O grupo tratado $(n=23)$ recebeu ácido fólico $5 \mathrm{mg} / \mathrm{dia}$ e o grupo controle $(n=26)$ recebeu placebo, ambos durante 3 meses. Para constatar a condição de subfertilidade, realizaram-se dois espermogramas prévios com intervalo de 15 dias entre o primeiro e segundo exame. Além disso, foi requerida abstenção da atividade sexual ou masturbação por 2 a 7 dias antes das coletas (conforme recomendações da OMS). Exames pré e pós-intervenção foram realizados no mesmo laboratório por duas profissionais, seguindo os critérios da OMS, 1999. Aplicou-se o teste qui-quadrado em ambos os grupos. Resultados: Observamos que não houve melhora estatisticamente significante em nenhum dos seguintes parâmetros: concentração, motilidade, morfologia e vitalidade dos espermatozóides.

Conclusão: O tratamento exclusivo com ácido fólico na dosagem de $5 \mathrm{mg} /$ dia não melhorou os parâmetros espermáticos em homens subférteis.

Palavras-chave: infertilidade masculina; suplementos antioxidantes; ácido fólico, espermograma; estresse oxidativo.

\section{RESUMEN}

Objetivo: Se cree que la suplementación oral con antioxidantes podrían reducir los daños causados por especies reactivas del oxígeno en el líquido seminal, y, en consecuencia, aumenta lacapacidad de fertilización de los espermatozoides debido a la mejora de los parámetrosseminales. Método: El objetivo de esta investigación es valorar el efecto de la suplementacióncon ácido fólico, por el análisis de semen, en 49 hombres con subfertilidad con edad mediana de 35,3 años $( \pm 7,7)$. El grupo experimental $(n=23)$ ha recibido $5 \mathrm{mg}$ de ácido fólico al día y el grupo control ( $\mathrm{n}$ $=26$ ) ha recibido placebo, ambos los grupos fueron tratados durante tres meses. Con el fin de confirmar la condición de subfertilidad, dos espermogramas fueron realizados con un intervalo de 15 días entre la primera y la segunda prueba. Además, la abstinencia de las relaciones sexuales y de la masturbación se requirieron por dos a cinco días antes de recoger las muestras de semen (de acuerdo con las recomendaciones de la OMS). Los exámenes seminales antes y después de la intervención fueron realizados en el mismo laboratorio por dos profesionales, de acuerdo con los criterios de la OMS, 1999. La prueba de chi-cuadrado fue aplicada para ambos los grupos.

Resultados: No hubo una mejora estadísticamente significativa en cualquiera de los siguientes parámetros: la concentración, la motilidad, la morfología y la vitalidad de los espermatozoides.

Conclusión: El tratamento con ácido fólico solo en dosis de $5 \mathrm{mg} /$ día no mejora los parámetros seminales en los hombres subfertiles. 
Palabras-Ilave: infertilidad masculina, suplementos antioxidantes, ácido fólico, espermograma, estrés oxidativo.

\section{INTRODUCTION}

Infertility is increasing each day; it is estimated that $15 \%$ of couple at reproductive age have difficulty getting pregnant and the male infertility accounts for up to half of all cases (Hamada et al., 2011; Pasqualotto, 2007; Showell et al., 2011). Nevertheless, there is not an apparent cause for the large number of andrologic disorders, a condition named idiopathic male infertility which is mainly related to changes in the lifestyle, environmental exposure and eating habits (Hamada et al., 2011; Isidori et al., 2006; Mendiola et al., 2009). Tremellen (2008) stated that one in twenty men in the general population will be subfertile.

The main tool to diagnose a man's capacity to reproduce is semen analysis, which evaluates the quality of semen in a variety of parameters. Some researches show that spermatic changes might be caused by the presence of high levels of reactive oxygen species (ROS) which can lead to cell damage (Ebisch et al., 2006; Hamada et al., 2011; Mendiola et al., 2009; Rolf et al., 1999; Young et al., 2008). It is suggested that ROS produced by leukocytes and spermatozoa are responsible for sperm damage and this contributes to the pathology in 30 to $80 \%$ of infertility cases (Esteves \& Agarwal, 2011). It is thought that oral supplementation with antioxidants could reduce this kind of damage and it could also increase the fertilizing capacity of spermatozoa due to improvement of sperm parameters.

The most commonly used antioxidants are vitamin E, vitamin C, carotenoids, ubiquinol and some micronutrients, such as folate and zinc (Eskenazi et al., 2005; Showell et al., 2011). Some researchers reported an improvement in semen parameters with antioxidants use, suggesting that such substances minimize the toxic effects of oxidative stress in spermatozoa, whether used alone or combined with other vitamins and micronutrients (Agarwal et al., 2005). There is scientific evidence for the antioxidant activity of the folic acid in a $5 \mathrm{mg} / \mathrm{day}$ dose, associated with Zinc for the treatment of subfertile men, and there were results showing beneficial effects or neutral effects (Ebisch et al., 2006; Ramasamy et al., 2012; Wong et al., 2002).

However, the combination of drugs makes it difficult to identify which component could have a beneficial effect on the semen parameters. Although folic acid is wide used for its beneficial effects on the pregnancy (Tamura \& Picciano, 2006), has low incidence of side effect and is cost accessible, to the moment this research was designed, we could not locate any study within the last 10 years that analyzed the effects of folic acid alone on semen sample of infertile males. Due to the controversy about the different effects of these substance and because many authors use a combination of them, the present work evaluated the effect of oral supplementation with folic acid alone in the quality of the sperm from subfertile men.

\section{MATERIALS AND METHODS}

A randomized, double-blind and placebo-controlled clinical trial was performed in the Human Reproduction Laboratory, Clinical Hospital, Federal University of Goias (LabRep/ HC-UFG) from February, 2009 to December, 2011.

At the LabRep, couples who tried pregnancy for at least one year follow a pre-established routine, which includes a throughout investigation to identify infertility and related causes. Initially, the man is submitted to a semen sample analysis. If the first sample demonstrates any alterations, a new sample is tested to confirm subfertility. The two semen specimens must be collected by masturbation at clinical sites at least 15 days apart and patients are required to have abstained from sexual intercourse or masturbation for two to seven days prior to sample collection, following WHO recommendations (1999).
During screening, all semen analyses were performed manually by two different medical annalists within one hour after the sample was collected and included measurements of sperm vitality, the volume of the ejaculate and determinations of the sperm concentration and the percentage of sperm with any evidence of flagellar movement (percentage motility). Within $24 \mathrm{~h}$ of sample collection, morphology was also analyzed using a microscope immersion analysis (100x). Subfertility was characterized by conditions such as oligozoospermy, astenozoospermy, teratozoospermy or oligo-asthenoteratozoospermy. Routinely at LabRep, as part of the treatment, patients with a positive diagnosis for subfertility also have their sexual hormones levels analyzed.

Patients with subfertile results in both samples were invited by the main researcher to participate at the study. The participation on the study did not affect in any way the subfertility treatment, nor was it conditioned to any financial support.

We calculated the sample size using OpenEpi with a $95 \%$ level of significance, a test power of $80 \%$. We considered the male infertility rate at the general population of $6 \%$ (Gurunath et al., 2011); we also considered that $36 \%$ of the patients who attend our clinic are infertile. With such criteria, we calculated a sample size of at 35 individuals. This study analyzed 49 male. Other studies, which analyzed the effect of different antioxidants on male infertility (including, but not exclusively, folic acid) had a similar sample size (Barbosa, 2009; Comhaire et al., 2005; Ghanem et al., 2010; Hawkes et al., 2009; Keskes-Ammar et al., 2003; Omu et al., 2008; Paradiso Galatioto et al., 2008; Piomboni et al., 2008; Tremellen et al., 2007; Tunc et al., 2009): who studied respectively, $48,30,52,42,51,45,30,50,44$ and 60 cases.

The sample included all subfertile male patients who did not take any additional supplement and/or vitamin other than the supplement provided, and who did not change eating habits during the follow-up period. All the men were required to be between the ages of 20 and 55 years at the time of enrollment. Patients with Folliclestimulating hormone (FSH) levels higher, azoospermy and patients treated with clomiphene citrate were excluded (Figure 1).

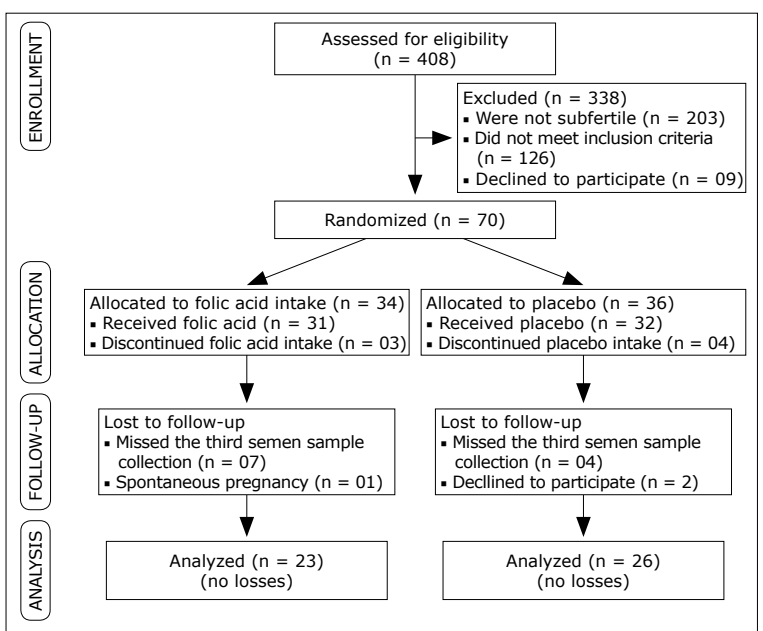

Figure 1. Fluxogram showing the allocation of participants and reasons for exclusion, 49 patients carried out the study protocol successfully.

An independent compounding pharmacy prepared bottles with 90 pills of folic acid or placebo, with the exact same appearance. Those bottles were sent to LabRep, where they were distributed to the patient through raffling off a letter ( $A$ or $B$ ), after the patient's consent to participate. For three months, patients in the experimental group received $5 \mathrm{mg}$ of folic acid a day and the control group received placebo. 
Within 15 days after the last pill intake, a new single semen sample was collected at clinical site by masturbation. Again, patients were required to have abstained from sexual intercourse or masturbation for five to seven days prior to sample collection, according to WHO recommendations (1999). The semen analysis was repeated manually by the same medical annalists within one hour after sample collection, with the same techniques used at screening. The results of follow-up sample were then compared to the results obtained during screening. The allocation of patients in both groups was not disclosed before analysis of follow-up samples was finished.

The treatment with folic acid was evaluated as effective if the performance of the spermogram had normal values after the intervention, considering all the following criteria: sperm concentration $\geq 20 \times 106 / \mathrm{mL}$; percentage motility A grade + $B$ grade $\geq 50 \%$ or $A$ grade alone $\geq 25 \%$; normal morphology percentage $\geq 30 \%$; and sperm vitality $\geq 50 \%$. We also collected data related to alcoholic beverage consumption and smoking habit, and these data were used in order to compare the studied groups. The results were expressed as average and standard deviation ( $\pm S D$ ); in order to compare variables, we used SPSS 17.0 (IBM Corp, Armonk, New York, EUA) to calculate the $x 2$ test (or Fisher's Exact whenever necessary) for statistical significance; with a confidence interval of $95 \%(a=$ $5 \%$; significant $p$ value $<0.05$ ).

The study was approved by the Ethics Committee of the UFG Clinical Hospital (protocol number CEP/HC-UFG 050/2009).

\section{RESULTS}

The enrollment and allocation of participants and reasons for exclusion are displayed in Figure 1; 49 patients carried out the study protocol successfully.

Patients were enrolled from February, 2009 to September, 2011; follow-up ended in December, 2011 and statistical analysis took place from January to March, 2012, which concluded the 3 year period planned for this study.

Table 1 shows the baseline characteristics of the two groups after the study protocol was successfully completed and it shows certain homogeneity between the groups. Their ages ranged between 23 to 56 years, and the average was 35.3 years $( \pm 7.7)$.

The effects of treatment were assessed by the performance of the sperm analysis after the intervention, and it was analyzed the concentration, motility, morphology and vitality of the spermatozoa.

Before the intervention, the average sperm concentration in millions/ml (Figure 2) in the experimental group was 25.91 $( \pm 24.09)$ and after the treatment it was $26.08( \pm 24.52)$. In the control group, the results for that same parameter were 20.85 ( \pm 19.69$)$ before intervention and $20.04( \pm 16.35)$ after the intervention. The difference found was not statistically significant $(p=0.92)$.

Regarding sperm motility, the averages of progressive motile sperm (Figure 3) for the experimental and placebo groups before the treatment were respectively $46.48 \%( \pm 14.87)$ and $49.23 \%( \pm 13.47)$. After the acid folic treatment, the average found in the experimental group was $48.26 \%$ $( \pm 10.72)$ and in the control group the average found was $49.65 \%( \pm 11.93)[p=0.99]$.

The average normal spermatozoa morphology (Figure 4) was $23.26 \%( \pm 2.86)$ before the treatment in the experimental group and after the intervention it as $23.91 \%$ $( \pm 3.68)$. The average found in the control group was $22.3 \%$ $( \pm 3.53)$ and $24.23 \%( \pm 3.06)$, respectively $(p=0.83)$.

The average found in the treated group for the spermatozoa vitality (Figure 5$)$ was $66.73 \%( \pm 8.73)$ before the treatment and $69.56 \%( \pm 7.96)$ after the acid folic treatment. For the control group the average was $65.77 \%( \pm 9.45)$ before the treatment and $65.38 \%( \pm 12.64)$ after the placebo treatment. The difference found was not statistically significant $(p=0.95)$. The analysis of the sperm parameters showed no significant differences between treatment and control groups (table 2 ).

Alcoholic beverage consumption was analyzed as a confounding factor; we didn't find any meaningful
Table 1. Comparability between experimental and control groups analyzed. LabRep/HC-UFG, 2012.

\begin{tabular}{lccc}
\hline & $\begin{array}{c}\text { Experimental } \\
(\mathbf{n = 2 3})\end{array}$ & $\begin{array}{c}\text { Control } \\
(\mathbf{n = 2 6})\end{array}$ & $\boldsymbol{P}$ \\
\hline Age (years) & $35.6(23-47)$ & $\begin{array}{c}36.8 \\
(24-56)\end{array}$ & 0.09 \\
\hline Concentration (x10\%/mL) & $25.9(1-108)$ & $\begin{array}{c}20.8 \\
(1-64)\end{array}$ & 0.17 \\
\hline Motility (\%) ${ }^{\text {a }}$ & $46.5(20-70)$ & $\begin{array}{c}49.2 \\
(25-80)\end{array}$ & 0.46 \\
\hline Morphology (\%) & $23.3(20-30)$ & $\begin{array}{c}22.3 \\
(15-30)\end{array}$ & 0.09 \\
\hline Vitality (\%) & $66.7(50-80)$ & $\begin{array}{c}65.8 \\
(45-85)\end{array}$ & 0.41 \\
\hline
\end{tabular}

a median value of progressive motile sperm ( $A$ grade $+B$ grade considered)

${ }^{b}$ average normal sperm morphology

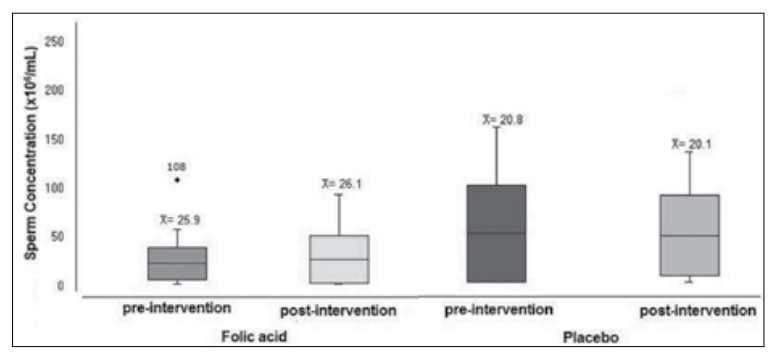

Figure 2. Concentration of spermatozoa in the experimental and control groups before and after folic acid therapy. LabRep/ HC-UFG, 2012.

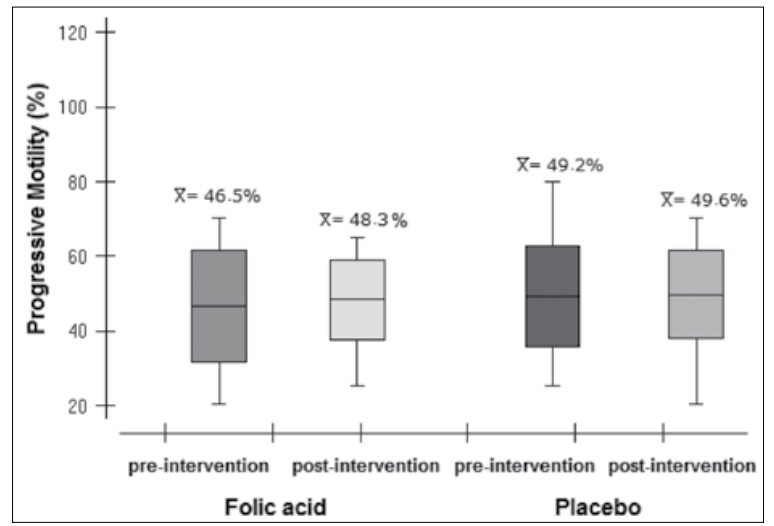

Figure 3. Progressive motility of spermatozoa in the experimental and control groups before and after placebo therapy. LabRep/ HC-UFG, 2012

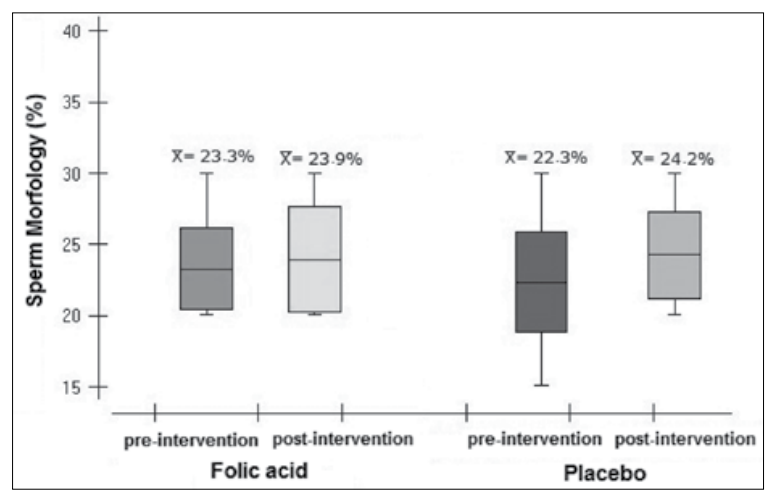

Figure 4. Morphology of spermatozoa in the experimental and control groups before and after folic acid therapy. LabRep/ HC-UFG, 2012. 


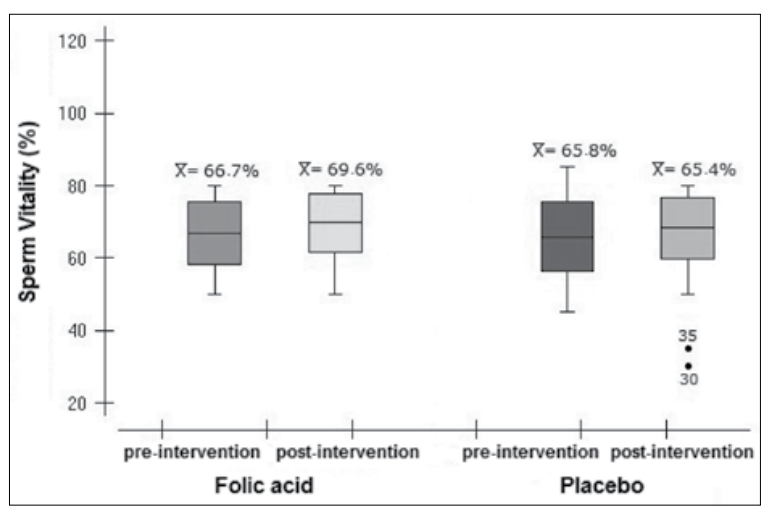

Figure 5. Vitality of spermatozoa in the experimental and control groups before and after placebo therapy. LabRep/HC-UFG, 2012.

Table 2. Patients according to group and effect on semen parameters. LabRep/HC-UFG, 2012.

\begin{tabular}{lccccc}
\hline \multicolumn{7}{c}{ Experimental } & \multicolumn{2}{c}{ Control } & \multirow{2}{*}{$\boldsymbol{p}^{*}$} \\
\hline & $\mathrm{N}$ & $\%$ & $\mathrm{~N}$ & $\%$ & \\
\hline $\begin{array}{l}\text { Improvement in } \\
\text { concentration }\end{array}$ & & & & & \\
\hline Yes & 11 & 47.8 & 09 & 34.6 & 0.51 \\
\hline No & 12 & 52.2 & 17 & 65.4 & \\
\hline $\begin{array}{l}\text { Improvement in } \\
\text { motility }\end{array}$ & & & & & \\
\hline Yes & 10 & 43.5 & 11 & 42.3 & 0.83 \\
\hline No & 13 & 56.5 & 15 & 57.7 & \\
\hline $\begin{array}{l}\text { Improvement in } \\
\text { morphology }\end{array}$ & & & & & \\
\hline Yes & 09 & 39.1 & 15 & 57.8 & 0.31 \\
\hline No & 14 & 60.9 & 11 & 42.2 & \\
\hline $\begin{array}{l}\text { Improvement in } \\
\text { vitality }\end{array}$ & & & & & \\
\hline Yes & 09 & 39.1 & 11 & 42.3 & 0.94 \\
\hline No & 14 & 60.9 & 15 & 57.7 & \\
\hline
\end{tabular}

* $\mathrm{X}^{2}$ test

differences in alcoholic beverage consumption habit in both control and intervention group due to the lack of improvement in the diagnosis of the spermogram $(p=0.18$ for the experimental group and $p=0.60$ for the control group). The same is true for the smoking habit $(p=0.17$ for the experimental group and $p=0.72$ for the control group).

\section{DISCUSSION}

When comparing our results with other studies, one should take into consideration the lack of studies using folic acid alone. The results of the present work show that treatment with folic acid in a dose of $5 \mathrm{mg} /$ day did not improve the main semen parameters in a significant way, with is similar to the findings of other authors who also tested the efficacy of oral antioxidant treatment either associated with other components or not (Greco et al., 2005b; Rolf et al., 1999; Safarinejad et al., 2011; Sigman et al., 2006; Tunc et al., 2009). On the other hand, different researches found statistically significant results (Barbosa, 2009; Comhaire et al., 2005; Ebisch et al., 2006; Ghanem et al., 2010; Hawkes et al., 2009; Keskes-Ammar et al., 2003; Omu et al., 2008; Paradiso
Galatioto et al., 2008; Piomboni et al., 2008; Tremellen et al., 2007; Wong et al., 2002).

There was a slight increase in the concentration of spermatozoa with a difference of $13.2 \%$ when compared to the control group, and this was also observed about the spermatozoa motility. Although these data are not statistically significant they are consistent with data reported by Barbosa (2009) who tested infertile Portuguese patients.

Despite being water-soluble, the folic acid inhibits lipid peroxidation in order to protect cell membrane and DNA from damage caused by free radicals (Ebisch et al., 2007). Folic acid is an essential vitamin important for cell proliferation; it works as a cofactor of enzymes involved in purine and pyrimidine synthesis, therefore being essential for DNA synthesis in spermatogenesis (Forges et al., 2008; Wong et al., 2002).

Systematic review of published data from Cochrane (2011) stated that the combined supplementation have shown increased fertilization rates of couples undergoing assisted reproductive technologies. The study included 34 studies in a total of 2876 couples and they concluded that the antioxidant use by the male partner was associated with a statistically significant increased pregnancy rate and live birth rate compared to control. However, this meta-analysis has neither identified the specific agents nor the optimal dosage for the treatment of infertile men.

Various authors used combinations of antioxidants (Ebisch et al., 2006; Ghanem et al., 2010; Imhof et al., 2011; Tremellen et al., 2007; Wong et al., 2002); although these drugs are combined in most studies it is important to develop more research about these interactions. These facts, as well as varying the dose interval make it difficult to standardize the therapy once one cannot identify the real active component. Hence, this study performed an evaluation of the folic acid effect alone. There are only few studies which used only one substance: Omu et al., (2008) studied the effects of Zinc; Hawkes et al., (2009) studied the effects of Selenium; and Safarinejad (2011), analyzed the effects of Omega3. Significant improvement in semen parameters were shown only in those which used Zinc or Omega 3.

Landau and Singer (1978) used a supplemental dose of $10 \mathrm{mg} /$ day for 30 days and observed as a result that the levels of this micronutrient increased in the blood and in the seminal fluid but it did not affect the sperm count, the sperm motility or the sperm DNA. It is important to note that this study was not randomized or placebo-controlled. Piombini et al., (2008), observed a statistically significant improvement in sperm motility and morphology, they used natural antioxidant compounds (beta glucan, papaya, lactotransferrin, and the vitamins $\mathrm{C}$ and $\mathrm{E}$ ). However, as Tunc et al., (2009), their studies were neither randomized nor placebo-controlled which make the positive effects they found less reliable.

Another aspect that should be analyzed is the common use of small samples and the population variation in males, from fertile men to several different levels of infertility, making it even more difficult to compare the studies.

Because of the variety of antioxidants evaluated, designing an ideal compound will be a challenge. Particular attention should be given to dosages and the number of ingredients used in order to develop optimized combinations. High doses of antioxidants should be avoided due to specific reactions which could lead to negative effects. High doses of vitamin A might have embryotoxic or teratogenic effects. High doses vitamin C can induce DNA damage (Ménézo et al., 2007). Selenium in high doses reduces the number of spermatozoa significantly in fertile males because it can lead to changes in the metabolism of thyroid hormones (Hawkes et al., 2009). Dosages of vitamin E less than $3200 \mathrm{mg} /$ day and dosages of vitamin C less than $4000 \mathrm{mg} /$ day are considered safe (Rolf et al., 1999).

On the other hand, lower doses and a combination of substances can result in beneficial effects. Greco et al., 
(2005a) randomized 64 infertile men with more than $15 \%$ of sperm DNA fragmentation. They were divided in two groups, one group received vitamins $C$ and $E(1 \mathrm{~g} /$ day each vitamin) and the other group was a placebo-controlled, they took the vitamins for two months. Although they did not notice any difference in the semen parameters the patients who received the antioxidants showed significant lower DNA fragmentation after the treatment. A further study from the same group showed that the vitamins $C$ and $E$ supplementation increased the rates of implantation and clinical pregnancy significantly for patients undergoing ICSI. Taking the etiology of male infertility into account, Kefer et al., (2009), Gharagozloo and Aitken (2011) state that free radicals might induce cell damage in the semen by some different means and they can affect significantly both the quality and the seminal viability. The scarcity of cytoplasm in spermatozoa reduces their ability to retain adequate amounts of molecules that could protect the cell from reactive oxygen species strike. In this way, the oxidative stress evaluation is extremely important. The determination of ROS levels in semen and the establishment of reference values may be useful in order to elaborate a treatment plan. Nowadays the male infertility investigation does not give any importance to the estimation of oxidative stress because of the excessive cost and the lack of standardized measures, but it has been described more than 30 direct or indirect tests (Kefer et al., 2009).

Agarwal et al., (2005) stated that the determination ROS levels in the seminal fluid would be helpful in order to predict the outcomes in IVF procedure, because they were related to the fertilization rates. The Intracitoplasmic Sperm Injection (ICSI) was developed to treat the male factor in the couple infertility. As a consequence, the conventional treatment of male infertility has become obsolete for some cases (Comhaire \& Mahmoud, 2003). Isidori et al., (2006), Mendiola et al., (2009) and Hamada et al., (2011) associated lifestyle such as feeding, smoking and alcohol drinking to idiopathic male infertility. Esteves and Agarwal (2011) claim that smoking may induce oxidative stress once it decreases the levels of antioxidants in the seminal plasma. No significant difference was found between the habit of smoking or alcohol consumption and the lack of improvement in the semen parameters. Further researches that also consider the occupational and environmental exposures are necessary in order to clarify these aspects.

There are few scientific benefits in the adoption of preventive measures and also in the elucidation of underlying causes of male infertility (Pasqualotto et al., 2003). Most of the treatment strategies have been established in order to apply the assisted reproduction techniques. These measures have made it possible for subfertile couples to conceive but they are restricted only to treat the infertility symptoms (Ebisch et al., 2007). The findings in the scientific literature are contradictory and further studies are essential for a better understanding of the mechanisms involved in oxidative stress of the ejaculate. This will enable new diagnostic and treatment systems to be developed in order to prevent free radicals cause damage to the spermatozoa. Researches must be designed so that the factors involved are controlled. This way the results can be interpreted and the controversies related to this topic will be clarified.

\section{CONFLICT OF INTEREST:}

Tatiana Moreira da Silva, Mônica Canêdo Silva Maia, Jalsi Tacon Arruda, Fabiana Carmo Approbato, Carolina Rodrigues de Mendonça and Mário Silva Approbato claim that there is not any conflict of interest.

\section{* Corresponding Author}

Email: tatiana.more@hotmail.com

Phone number: 55 (62) 3269-8278

Postal Address: $1^{a}$ Avenida, $s / n^{\circ}$, Setor Universitário, CEP: 74605-020, Goiânia-GO, Brazil.

Laboratory of Human Reproduction, Clinical Hospital, Federal University of Goias, Goiânia, Goiás, Brazil

\section{REFERENCES}

Agarwal A, Prabakaran SA, Said TM 2005. Prevention of Oxidative Stress Injury to Sperm. Journal of Andrology, 26, 654-660.

Barbosa FFS 2009. Influência dos antioxidantes na qualidade do sémen de homens em tratamento de fertilidade. Mestrado em Biologia Humana e Ambiente Dissertação, Universidade de Lisboa, Lisboa, 70 pp.

Comhaire FH, El Garem Y, Mahmoud A, Eertmans F, Schoonjans F 2005. Combined conventional/antioxidant "Astaxanthin" treatment for male infertility: a double blind, randomized trial. Asian J Androl, 7, 257-262.

Comhaire FH, Mahmoud A 2003. The role of food supplements in the treatment of the infertile man. Reproductive biomedicine online, 7, 385-391.

Ebisch IMW, Pierik FH, De Jong FH, Thomas CMG, SteegersTheunissen RPM 2006. Does folic acid and zinc sulphate intervention affect endocrine parameters and sperm characteristics in men? Int J Androl, 29, 339-345.

Ebisch IMW, Thomas CMG, Peters WHM, Braat DDM, SteegersTheunissen RPM 2007. The importance of folate, zinc and antioxidants in the pathogenesis and prevention of subfertility. Human Reproduction Update, 13, 163-174.

Eskenazi B, Kidd SA, Marks AR, Sloter E, Block G, Wyrobek AJ 2005. Antioxidant intake is associated with semen quality in healthy men. Human Reproduction, 20, 1006-1012.

Esteves SC, Agarwal A 2011. Novel concepts in male infertility. Int Braz J Urol, 37, 5-15.

Forges T, Pellanda H, Diligent C, Monnier P, Guéant J-L 2008. Les folates: quel impact sur la fertilité? Gynecol Obstet Fertil, 36, 930-939.

Ghanem H, Shaeer O, El-Segini A 2010. Combination clomiphene citrate and antioxidant therapy for idiopathic male infertility: a randomized controlled trial. Fertility and sterility, 93, 2232-2235.

Gharagozloo P, Aitken RJ 2011. The role of sperm oxidative stress in male infertility and the significance of oral antioxidant therapy. Human Reproduction, 26, 1628-1640.

Greco E, Iacobelli M, Rienzi L, Ubaldi F, Ferrero S, Tesarik J 2005a. Reduction of the Incidence of Sperm DNA Fragmentation by Oral Antioxidant Treatment. Journal of Andrology, 26, 349-353.

Greco E, Romano S, Iacobelli M, Ferrero S, Baroni E, Minasi MG, Ubaldi F, Rienzi L, Tesarik J 2005b. ICSI in cases of sperm DNA damage: beneficial effect of oral antioxidant treatment. Human Reproduction, 20, 2590-2594.

Gurunath S, Pandian Z, Anderson RA, Bhattacharya S 2011. Defining infertility - a systematic review of prevalence studies. Human Reproduction, 17(5):575-88.

Hamada A, Esteves SC, Agarwal A 2011. Unexplained male infertility: potential causes and management. Human Andrology, 1, 2-16 10.1097/1001.XHA.0000397686.000038 2729.0000397609.

Hawkes W, C, Alkan Z, Wong K 2009. Selenium supplementation does not affect testicular selenium status or semen quality in North American men. Journal of Andrology, 30, 525-533.

Imhof M, Lackner J, Lipovac M, Chedraui P, Riedl C 2011. Micronutrient Supplementation Increases Sperm Quality in the Sub-fertile Male. European Urological Review, 6, 120-123.

Isidori AM, Pozza C, Gianfrilli D, Isidori A 2006. Medical treatment to improve sperm quality. Reproductive biomedicine online, 12, 704-714.

Kefer JC, Agarwal A, Sabanegh E 2009. Role of antioxidants in the treatment of male infertility. International Journal of Urology, 16, 449-457.

Keskes-Ammar L, Feki-Chakroun N, Rebai T, Sahnoun Z, Ghozzi H, Hammami S, Zghal K, Fki H, Damak J, Bahloul A 2003. Sperm oxidative stress and the effect of an oral vitamin $E$ and selenium supplement on semen quality in infertile men. Archives of andrology, 49, 83-94.

Landau B, Singer R, Klein T, Segenreich E 1978. Folic acid levels in blood and seminal plasma of normo- and oligospermic patients prior and following folic acid treatment. Experientia, 34, 1301-1302. Mendiola J, Torres-Cantero AM, Agarwal A 2009. Lifestyle factors and male infertility: an evidence-based review. Arch Med Sci, 5, S3-S12. 
Ménézo YJ, Hazout A, Panteix G, Robert F, Rollet J, Cohen-Bacrie $P$, Chapuis $F$, Clement $P$, Benkhalifa M 2007. Antioxidants to reduce sperm DNA fragmentation: an unexpected adverse effect. Reproductive biomedicine online, 14, 418-421.

Omu AE, Al-Azemi MK, Kehinde EO, Anim JT, Oriowo MA, Mathew TC 2008. Indications of the mechanisms involved in improved sperm parameters by zinc therapy. Medical principles and practice : international journal of the Kuwait University, Health Science Centre, 17, 108-116.

Paradiso Galatioto G, Gravina GL, Angelozzi G, Sacchetti A Innominato PF, Pace G, Ranieri G, Vicentini C 2008. May antioxidant therapy improve sperm parameters of men with persistent oligospermia after retrograde embolization for varicocele? World J Urol, 26, 97-102.

Pasqualotto FF 2007. Investigação e reprodução assistida no tratamento da infertilidade masculina. Revista Brasileira de Ginecologia e Obstetrícia, 29, 103-112.

Pasqualotto FF, Locambo CV, Athayde KS, Arap S 2003. Measuring male infertility: epidemiological aspects. Revista do Hospital das Clínicas, 58, 173-178.

Piomboni P, Gambera L, Serafini F, Campanella G, Morgante G, De Leo V 2008. Sperm quality improvement after natural anti-oxidant treatment of asthenoteratospermic men with leukocytospermia. Asian J Androl, 10, 201-206.

Ramasamy R, Stahl PJ, Schlegel PN 2012. Medical therapy for spermatogenic failure. Asian J Androl, 14.

Rolf C, G.Cooper T, H.Yeung C, Nieschlag E 1999. Antioxidant treatment of patients with asthenozoospermia or moderate oligoasthenozoospermia with high-dose vitamin $C$ and vitamin E: a randomized, placebo-controlled, double-blind study. Human Reproduction, 14, 1028-1033.

Safarinejad MR, Shafiei N, Safarinejad S 2011. A Prospective Double-blind Randomized Placebo-controlled Study of the Effect of Saffron (Crocus sativus Linn.) on Semen Parameters and Seminal Plasma Antioxidant Capacity in Infertile Men with Idiopathic Oligoasthenoteratozoospermia. Phytother. Res, 25, 508-516.
Showell MG, Brown J, Yazdani A, Stankiewicz MT, Hart RJ 2011. Antioxidants for male subfertility. Cochrane database of systematic reviews (Online), CD007411.

Sigman M, Glass S, Campagnone J, Pryor JL 2006. Carnitine for the treatment of idiopathic asthenospermia: a randomized, double-blind, placebo-controlled trial. Fertility and sterility, 85, 1409-1414.

Tamura T, Picciano MF 2006. Folate and human reproduction. Am J Clin Nutr, 83, 993-1016.

Tremellen K 2008. Oxidative stress and male infertility-a clinical perspective. Human Reproduction Update, 14, 243-258.

Tremellen K, Miari G, Froiland D, Thompson J 2007. A randomised control trial examining the effect of an antioxidant (Menevit) on pregnancy outcome during IVF-ICSI treatment. Australian and New Zealand Journal of Obstetrics and Gynaecology, 47, 216-221.

Tunc O, Thompson J, Tremellen K 2009. Improvement in sperm DNA quality using an oral antioxidant therapy. Reproductive biomedicine online, 18, 761-768.

Wong WY, Merkus HMWM, Thomas CMG, Menkveld R, Zielhuis GA, Steegers-Theunissen RPM 2002. Effects of folic acid and zinc sulfate on male factor subfertility: a double-blind, randomized, placebo-controlled trial. Fertility and sterility, 77, 491-498.

World Health Organization 1999. WHO Laboratory manual for the examination of human semen and sperm-cervical mucus interaction. 4th edition. 138 pages.

Young SS, Eskenazi B, Marchetti FM, Block G, Wyrobek AJ 2008. The association of folate, zinc and antioxidant intake with sperm aneuploidy in healthy non-smoking men. Human Reproduction, 23, 1014-1022. 